\title{
FACTORS AFFECTING INDIVIDUAL INVESTOR DECISION MAKING BEHAVIOUR - A STUDY ON INVESTORS IN DHAKA \& CHITTAGONG, BANGLADESH
}

\author{
MD ZOHIR RAIHAN ${ }^{\# 1}$, MD SOHEL HOSSAIN ${ }^{\# 2}$, NAIMUR RAHMAN ${ }^{\# 3}$, OSAMA BIN SAJJAD ${ }^{\# 4}$, \\ MAHABUBA FATEMA MOU ${ }^{\# 5}$ \\ ${ }^{\# 1}$ Department of Business Administration, Kaiserslautern University Of Applied Sciences, Germany \\ ${ }^{\# 2}$ Department of Business Administration, American International University Bangladesh \\ ${ }^{\# 3}$ Faculty of Business Studies, Oth Amberg- Weiden, Germany \\ ${ }^{\# 4}$ Faculty of Business Studies, Oth Amberg- Weiden, Germany \\ ${ }^{\# 5}$ Department of Business Administration, South Westphalia University Of Applied Sciences, Germany \\ ${ }^{I}$ zohirraihan1861@gmail.com, ${ }^{2} \underline{\text { h.sohel25@gmail.com, }}{ }^{3}$ naimrahman012@gmail.com, ${ }^{4}$ osamabinsajiad@gmail.com, \\ ${ }^{5}$ mahbubamou1701@gmail.com
}

\begin{abstract}
In this study, it was aimed to investigate the factors that influence individual investor decision making behavior and also to make a comparative study of the investment behavior of individual investors from Dhaka \& Chittagong, Bangladesh. While conducting this study, the researchers adopted a model questionnaire for the purpose of doing a survey. In this study 100 respondents have been surveyed. Investment decisions have gained importance due to the general increase in employment opportunities and economic development of a nation.

While making investment access, an investor must consider all factors and impact that can affect investment decision making process. This paper also depicts the significance of all the factors that are necessary to be considered. A number of statistical tools such as correlation and regression analysis have been applied to analyze the collected data from the survey. Statistical software SPSS (version- 22) has been used to make this analysis. The findings of the study reflect that the factors such as Accounting Information, Advocate Recommendation, Personal Financial Needs, Neutral Information and Self Image have a significant impact on investor's investment decision makings. Moreover, Factors influencing investment decision varies from time to time, place to place, person to person.
\end{abstract}

Keywords: Individual Investor decision, Accounting information, Factors Affecting, Investor's Decision.

\section{INTRODUCTION}

Researchers were always enthusiastic about investment thus they explored it in a plethora of ways. The findings of those researchers led to the conclusion that the investment decision depends on personal characteristics. Some key features play a vital role in the process of decision making. When it comes to investment, a sole connection between risk and return has been noticed. Depending on their particular need, risk appetite, and anticipated return, investors choose avenues. Investment avenues can be divided widely into two fields, namely, real investment and financial investment. Real investments involve a tangible (physical) asset, such as property, machinery, etc. Financial investments, on the other hand, involve investment in financial instruments like insurance policies, shares, debentures, etc.

The right investment decisions are made by the investor by analyzing various factors. So, using fundamental insight, analytical analysis and judgment, investors typically evaluate investments. It is assumed that the five factors (Accounting Information, Advocate Recommendation, Personal Financial Needs, Neutral Information and Self -Image) influence individuals' investment decisions. These factors will focus upon how investors interpret and act on information to make investment decisions. This study examines the various factors affecting investment decision individual investors from Dhaka \& Chittagong, Bangladesh. 


\section{LITERATURE REVIEW}

Many hypotheses have been designed to clarify what factors influenced an individual's investment. While the literature covers a wide variety of such hypotheses, this analysis will highlight five key factors that have been consistently explored in the reviewed literature. In this research, the study is carried out on factors such as accounting details, self/company image, demographics (age, gender), which influence the conduct of investor decision-making.

Researchers have been doing serious studies about how the individual investor state of mind needs to do when making investment decisions. In a research paper by Dr. Taqadus Bashir and Aaqiba Javed (April 2013) on "the factors affecting the decision-making of individual investors in Pakistan," Dr. Taqadus Bashir and Aaqiba Javed (April 2013) showed that accounting information, personal financial needs, firm image and advocate advice are the variables that somehow influence individual conduct, but accounting information has the greatest effect on Pakistan's investor behavior.

\section{The Neutral-Information}

Investor reaction to corporate event announcements was investigated by Kadiyala and Rau, (2004). They have concluded that investors seem to be under-reacting to previous information and to the information conveyed by the case, contributing to various patterns. Two opposing models of irrational investors have been presented in the behavioral finance literature. Conduct. In the first model, investors appear to overreact to results, resulting in a trend of long-term return reversals when companies report corporate events such as new stock issues. In the above model, Investors under react to data, leading to long-term continuation of returns when companies announce corporate Incidents such as open-market repurchases of stock or tender offers funded by cash. Types of behavior have been partly regarded with suspicion because they cannot reconcile why investors tend to overreact to a corporate. For instance, Fama (1998) argues that the long-run abnormal return evidence cannot be explained by behavioral models because Investors' overreaction to some activities and under-reaction to others ensures that investors are, on average, investors Unbiased in their response to information. Loughran and Ritter, (1995) argue that the overreaction of investors explains Following an experienced equity offering (SEO), the negative long-run abnormal returns, an inference focused on the Strong previous output of companies announcing an SEO.

\section{The Accounting-Information}

Baker and Haslem (1973) contend that investors are mainly concerned with future aspirations, It is of great importance to investors to understand earnings forecasts and historical evidence. Study, on the other hand, Lee and Tweedie $(1975,1976$, and 1977) show that the general public faces issues with understanding the private sector's financial reporting. Blume and Friend (1978) provide evidence that the key risk factors used by individuals are both price and earnings volatility, while Schlarbaum et al. (1978) contrasts the performance of individuals with that of experienced fund managers and finds that the former demonstrate significant expertise in their investment decision making. Lease et al., (1974), describes citizens as "investors" Instead of "traders" because they are long-term minded and short-term yields have no appeal. Furthermore, Lewellen et al., (1977) show that the key source of knowledge for investors is fundamental or technological information analyzing. Antonides and Van Der Sar (1990) suggest that an investment's perceived risk is lower if an asset has an asset. Recently, the value has increased, consistent with the findings of (blume and friend, 1978). Nagy and Obenberger (1994) analyzed the degree to which a list of 34 factors influences the shareholders' Perception, and provide proof of a role for a combination of financial and non-financial factors. Statman and Fisher, Based on the general consensus that the investment decision is a difficult one, (1997) suggests that investors are not Only risk and return concerns are concerned when purchasing shares, but some other factors are often taken into account.

\section{The Self-Image/Firm-Image Coincidence}

The need for social knowledge by individual investors was examined by Epstein, (1994). The findings suggest that the usefulness to corporate shareholders of annual reports. In addition, a majority of the shareholders have surveyed the organization needs to report on corporate integrity, relationships with staff and engagement in the society. Conductual Daniel, Hirshleifer, and Subrahmanyam (1998) and Hong and Stein (1999) suggested models also predict Short-run continuations of return and long-run reversals of return. Daniel et al. say that educated investors are overconfident of the private signal that they get about the value of a stock. Biased self-attribution improves their overconfidence when their private information is in harmony with public information. When information from the public is biased self-attribution leads to dismissal of the data as noise and is not in harmony with their private signal.

\section{The Advocate-Recommendation}

An analyst recommendation can be answered in one of four ways by the investor who already owns a stock: the on a sell recommendation, the investor may hold stock, the investor may sell stock on a hold recommendation, and the investor may sell stock on a hold recommendation. On a hold recommendation, the investor can hold stock, or on a sell recommendation, the investor can sell stock. Prior accounting studies explored how investors are influenced by the form of analyst and the quality of the analyst report the actions (Francis and Soffer, 1997). They discovered this because of the nature of analyst incentives to problem Positive suggestions, investors more heavily consider other details in the analyst report when they are stronger observe a purchase rather than a suggestion to sell. This consideration includes brokerage buying recommendations. Houses and stock brokers for individual recommendations marginally loaded on this from friends or colleagues as a factor, too. Malmendier and Shanthikumar (2003) have attempted to address the question: are small investors naive? They find that, after positive large investors generate abnormal volumes of buyer-initiated trader's recommendation only if there is no connection with the analyst. After all positive, small traders exert abnormal buy pressure Recommendations, including those of analysts with affiliation. The variables studied by Krishnan and Booker, (2002) Influence of investor decisions that use the opinions of analysts to arrive at a short-term decision to keep or sell a stock. The findings indicate that the analyst 
summary recommendation report has a strong form, i.e. one with additional knowledge that further supports the position of the analysts, it decreases the disposition error for gains and the disposition error for losses is also minimized.

\section{The Personal-Financial-Needs}

The theory of Prospect implies that certain results are over-weighted in comparison to unknown results and that the value for gains and losses, functions are different (Shefrin and Statman, 1985); (Weber and Camerer, 1998). Rational, Rational Logic implies that when faced with a stock with unfavorable future expectations, people should sell the stock regardless of their current state of benefit or loss. Previous studies, however, on sunken costs and the escalation of Engagement illustrates that people can get trapped in the lack of action, even to the point of throwing good Cash After Evil (Arkes and Blumer 1985; Brockner 1992; Staw and Hoang 1995). Thus, rather than selling and taking a guaranteed loss, individuals may choose to keep a losing stock and bet on the future and may even become more committed to keeping the stock.

\section{CONCEPTUAL FRAMEWORK}

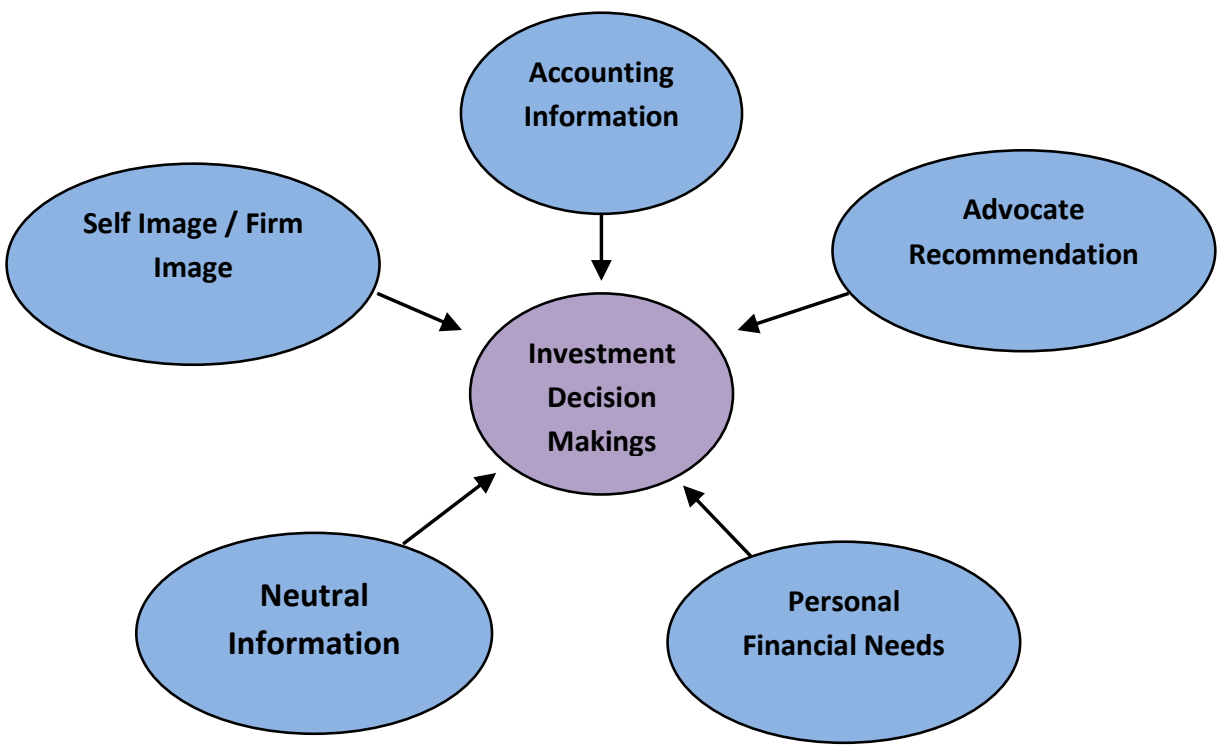

Figure: 1 - Conceptual framework

\section{RESEARCH OBJECTIVES}

This study is designed with the following objectives:

1. To examine the elements linked with self-image/firm image have an impact on the decision making of the capitalist.

2. To determine whether the components of accounting information have a relation to the behavior of the stockholder.

3. To determine the interconnection between neutral information and the Investment Decision Makings.

4. To know whether the factor related to advocate recommendation have an effect on investor's investment decision makings.

5. To examine the components of personal financial needs plays a role in the decision making of a particular investor.

\section{SIGNIFICANCE OF THE STUDY}

Investment decisions are affected by many variables. It is an acceptable fact that the investors are the centric point to the monetary market. The behavior of investors is not a stable one. It varies from place to place and security to security. It is therefore important to define the variables that influence investment decisions. In order to boost investment and formulate apposite theories and policies, it is important to understand how investors are invests in different sectors. It is important to understand how investors invest in various sectors in order to improve investment and to formulate relevant theories and 
policies. As a developing nation, Bangladesh is becoming more economically strong, needing enormous capital for various development activities. In order to improve investment among individual investors, the investment behavior of individuals must be analyzed and the factors motivating them to invest must be established, so that idle savings can be channeled into investment.

\section{METHODOLOGY}

The objective of this research is to measure the factors that affect on investor's decision Making \& its behavior. It is a quantitative research. We adopted a questionnaire to conduct a survey, whereas the respondents were 100, who were living in Dhaka \& Chittagong. A convenience sampling method has been used to select the samples. Tools and techniques used in analyzing the collected data and information were mostly statistical in nature. Statistical Techniques such as reliability analysis and factor analysis were done with the help of SPSS-22 software.

\begin{tabular}{|c|c|c|c|}
\hline \multicolumn{4}{|c|}{ Case Processing Summary } \\
\hline & & $\mathrm{N}$ & $\%$ \\
\hline \multirow[t]{3}{*}{ Cases } & Valid & 100 & 100.0 \\
\hline & Excluded $^{\mathrm{a}}$ & 0 & .0 \\
\hline & Total & 100 & 100.0 \\
\hline
\end{tabular}

Table: 1- shows Case Processing Summary

\begin{tabular}{|c|c|}
\hline \multicolumn{2}{|c|}{ Reliability Statistics } \\
\hline Cronbach's Alpha & N of Items \\
\hline .547 & 21 \\
\hline
\end{tabular}

Table: 2- Test of Reliability

The value of Cronbach's alpha $(\alpha=.547)$ on 21 items of the questionnaire show that there is a standard level of internal consistency for our scale with the specific sample.

\section{Data Analysis:}

\section{Demographic Analysis -}

\begin{tabular}{|c|c|r|r|r|r|}
\hline \multicolumn{7}{|c|}{ Gender of the respondent } \\
\hline \multirow{2}{*}{ Valid } & Frequency & \multicolumn{1}{c|}{ Percent } & Valid Percent & Cumulative Percent \\
\cline { 2 - 6 } & Male & 64 & 64.0 & 64.0 & 64.0 \\
\cline { 2 - 6 } & Female & 36 & 36.0 & 36.0 & 100.0 \\
\cline { 2 - 6 } & Total & 100 & 100.0 & 100.0 & \\
\hline
\end{tabular}

Table no 3: Shows Gender of respondent

Table 3 displays that the majority of respondents are male which is $65 \%$ and female is $36 \%$.

\begin{tabular}{|l|l|r|r|r|r|}
\hline \multicolumn{2}{|c|}{ Age } \\
\hline \multirow{4}{*}{ Valid } & Frequency & Percent & Valid Percent & Cumulative Percent \\
\cline { 2 - 6 } & Below 20 & 10 & 10.0 & 10.0 & 10.0 \\
\cline { 2 - 6 } & Between 21-30 & 73 & 73.0 & 73.0 & 83.0 \\
\cline { 2 - 6 } & Between 31-50 & 14 & 14.0 & 14.0 & 97.0 \\
\cline { 2 - 6 } & Above 50 & 3 & 3.0 & 3.0 & 100.0 \\
\cline { 2 - 6 } & Total & 100 & 100.0 & 100.0 & \\
\hline
\end{tabular}

Table no 4: Shows respondent age 
The table 4 shows that the majority of the investors are between 21 to 30 ( $73 \%$ of the total sample), while $14 \%$ of the respondents are from 31-50 and 10\% of the sample having the young ages which is below 20 and $3 \%$ of the respondent are above 50 .

\begin{tabular}{|l|l|r|r|r|r|}
\hline \multicolumn{7}{|c|}{ What Kind of Investment do you prefer most? } \\
\hline \multirow{5}{*}{ Valid } & Business & Frequency & Percent & Valid Percent & Cumulative Percent \\
\cline { 2 - 7 } & Gold/Silver & 65 & 65.0 & 65.0 & 65.0 \\
\cline { 2 - 7 } & Fixed Deposit & 3 & 3.0 & 3.0 & 68.0 \\
\cline { 2 - 7 } & Shares/Debentures & 16 & 16.0 & 16.0 & 84.0 \\
\cline { 2 - 7 } & Insurance & 2 & 2.0 & 2.0 & 86.0 \\
\cline { 2 - 7 } & Real Estates & 7 & 7.0 & 7.0 & 93.0 \\
\cline { 2 - 7 } & Total & 7 & 7.0 & 7.0 & 100.0 \\
\hline
\end{tabular}

Table no 5: Shows investment preference

From the table 5, it is noticeable that most of the investors are desired to invest in Business sector (65\%) and respectively, gold/silver (3\%), fixed deposit (16\%), Shares/debentures (2\%), insurance (7\%), real estate (7\%).

\begin{tabular}{|c|c|c|c|c|c|}
\hline \multicolumn{6}{|c|}{ While investing your money, which factor you prefer most? } \\
\hline & & Frequency & Percent & Valid Percent & Cumulative Percent \\
\hline \multirow[t]{5}{*}{ Valid } & Liquidity & 3 & 3.0 & 3.0 & 3.0 \\
\hline & High Return & 46 & 46.0 & 46.0 & 49.0 \\
\hline & Low Risk & 37 & 37.0 & 37.0 & 86.0 \\
\hline & Company Reputation & 14 & 14.0 & 14.0 & 100.0 \\
\hline & Total & 100 & 100.0 & 100.0 & \\
\hline
\end{tabular}

Table no 6: Shows factors of preference

The table 6 shows that among the 100 respondent only $3 \%$ respondent consider liquidity, while considering investment return $46 \%$ out $100 \%$ prefer high return and $37 \%$ respondent prefer low risk. In case of company reputation, only $14 \%$ prefer out of $100 \%$.

\begin{tabular}{|c|c|r|r|r|r|}
\hline \multicolumn{7}{|c|}{ What is the time period you prefer to invest? } \\
\hline \multirow{3}{*}{ Valid } & \multicolumn{1}{|c|}{ Frequency } & \multicolumn{1}{c|}{ Percent } & \multicolumn{1}{c|}{ Valid Percent } & Cumulative Percent \\
\cline { 2 - 6 } & Short Term & 22 & 22.0 & 22.0 & 22.0 \\
\cline { 2 - 6 } & Mid Term & 48 & 48.0 & 48.0 & 70.0 \\
\cline { 2 - 6 } & Long Term & 30 & 30.0 & 30.0 & 100.0 \\
\cline { 2 - 6 } & Total & 100 & 100.0 & 100.0 & \\
\hline
\end{tabular}

Table no 7: Shows length of time

The table 7 shows that the majority of respondent (48\%) are willing to go for mid-term investment, whereas $22 \%$ respondents are willing to go short-term investment and only $30 \%$ are prefer long term investment. 


\begin{tabular}{|c|c|c|c|c|}
\hline \multicolumn{5}{|c|}{ Model Summary } \\
\hline Model & $\mathrm{R}$ & $\mathrm{R}$ Square & Adjusted R Square & Std. Error of the Estimate \\
\hline 1 & $.678^{\mathrm{a}}$ & .460 & .431 & .24690 \\
\hline \multicolumn{7}{|c|}{ a. Predictors: (Constant), AVG_AI, AVG_AR, AVG_NI, AVG_SI, AVG_PFN } \\
\hline
\end{tabular}

Table: 8- model summary

\begin{tabular}{|c|c|c|c|c|c|c|}
\hline \multicolumn{7}{|c|}{ ANOVA $^{\mathrm{a}}$} \\
\hline \multicolumn{2}{|c|}{ Model } & Sum of Squares & Df & Mean Square & $\mathrm{F}$ & Sig. \\
\hline \multirow[t]{3}{*}{1} & Regression & 4.874 & 5 & .975 & 15.990 & $.000^{\mathrm{b}}$ \\
\hline & Residual & 5.730 & 94 & .061 & & \\
\hline & Total & 10.604 & 99 & & & \\
\hline
\end{tabular}

Table no 09: Shows ANOVA

The ANOVA table shows the R square value is 0.460 which is impressive. It means $46 \%$ of variance in 'Investment decision making' is explained by the predictors (dependent variables) and adjusted $\mathrm{R}$ square is also 0.460 .

\begin{tabular}{|c|c|c|c|c|c|c|}
\hline \multicolumn{7}{|c|}{ Coefficients $^{\mathbf{a}}$} \\
\hline \multicolumn{2}{|c|}{ Model } & \multicolumn{2}{|c|}{ Unstandardized Coefficients } & \multirow{2}{*}{$\begin{array}{c}\text { Standardized Coefficients } \\
\text { Beta } \\
\end{array}$} & \multirow[t]{2}{*}{$\mathrm{t}$} & \multirow[t]{2}{*}{ Sig. } \\
\hline & & $\mathrm{B}$ & Std. Error & & & \\
\hline \multirow[t]{6}{*}{1} & (Constant) & .130 & .219 & & .594 & .554 \\
\hline & AVG_SI & .206 & .074 & .226 & 2.783 & .007 \\
\hline & AVG_NI & .071 & .078 & .076 & .918 & .361 \\
\hline & AVG_AR & .443 & .104 & .346 & 4.265 & .000 \\
\hline & AVG_PFN & .292 & .081 & .308 & 3.632 & .000 \\
\hline & AVG_AI & .069 & .090 & .063 & .768 & .444 \\
\hline
\end{tabular}

Table no 10: Shows Coefficient

The coefficients tell us how many units dependent variable change for a single unit change in each predictor. Like so, 1 unit increase in 'Self Image/Firm Image' corresponds to 0.206 unit increase in 'Investment Decision Makings' and so on. Here all the coefficients are positive numbers that explain positive correlation between dependent variable (Investment Decision Makings) and independent variables (Accounting Information, Advocate Recommendation, Personal Financial Needs, Neutral Information, Self Image/Firm Image). 


\begin{tabular}{|c|c|c|c|c|c|c|c|}
\hline \multicolumn{8}{|c|}{ Correlations } \\
\hline & & AVG_SI & $\begin{array}{c}\text { AVG_N } \\
\text { I }\end{array}$ & AVG_AR & $\begin{array}{c}\text { AVG_PF } \\
\mathrm{N} \\
\end{array}$ & AVG_IDM & $\begin{array}{c}\text { AVG_A } \\
\text { I }\end{array}$ \\
\hline \multirow{3}{*}{ AVG_SI } & Pearson Correlation & 1 & $.268^{* *}$ & .192 & .181 & $.386^{* *}$ & $.267^{* *}$ \\
\hline & Sig. (2-tailed) & & .007 & .055 & .071 & .000 & .007 \\
\hline & $\mathrm{N}$ & 100 & 100 & 100 & 100 & 100 & 100 \\
\hline \multirow[t]{3}{*}{ AVG_NI } & Pearson Correlation & $.268^{* *}$ & 1 & .170 & $.314^{* *}$ & $.307^{* * *}$ & $.235^{*}$ \\
\hline & Sig. (2-tailed) & .007 & & .090 & .001 & .002 & .019 \\
\hline & $\mathrm{N}$ & 100 & 100 & 100 & 100 & 100 & 100 \\
\hline \multirow[t]{3}{*}{ AVG_AR } & Pearson Correlation & .192 & .170 & 1 & $.319^{* *}$ & $.511^{* *}$ & .166 \\
\hline & Sig. (2-tailed) & .055 & .090 & & .001 & .000 & .099 \\
\hline & $\mathrm{N}$ & 100 & 100 & 100 & 100 & 100 & 100 \\
\hline \multirow[t]{3}{*}{ AVG_PFN } & Pearson Correlation & .181 & $.314^{* *}$ & $.319^{* *}$ & 1 & $.501^{* * *}$ & $.280^{* *}$ \\
\hline & Sig. (2-tailed) & .071 & .001 & .001 & & .000 & .005 \\
\hline & $\mathrm{N}$ & 100 & 100 & 100 & 100 & 100 & 100 \\
\hline \multirow[t]{3}{*}{ AVG_IDM } & Pearson Correlation & $.386^{* *}$ & $.307^{* * *}$ & $.511^{* *}$ & $.501^{* *}$ & 1 & $.285^{* *}$ \\
\hline & Sig. (2-tailed) & .000 & .002 & .000 & .000 & & .004 \\
\hline & $\mathrm{N}$ & 100 & 100 & 100 & 100 & 100 & 100 \\
\hline \multirow[t]{3}{*}{ AVG_AI } & Pearson Correlation & $.267^{* *}$ & $.235^{*}$ & .166 & $.280^{* *}$ & $.285^{* *}$ & 1 \\
\hline & Sig. (2-tailed) & .007 & .019 & .099 & .005 & .004 & \\
\hline & $\mathrm{N}$ & 100 & 100 & 100 & 100 & 100 & 100 \\
\hline
\end{tabular}

Table no 11: Shows Correlations

Table 11 shows the correlation among the variables (both dependent and independent variables). The results show very strong correlation among the variables. The strongest correlation is found in between Investment Decision Makings and Advocate Recommendation which is 0.511 . The value 0.511 also indicates stronger correlation between Advocate Recommendation and Investment Decision Makings. The correlation matrix table shows that all the variables are strongly correlated with each other.

\section{CONCLUSION \& RECOMMENDATIONS}

This study aims to assess the variables that influence the investment decision-making of investors. The findings of this research indicate that the investment decision-making of the investor is substantially affected by all five factors (Accounting Information, Advocate Recommendation, Personal Financial Needs, Neutral Information and Self -Image). Investors typically prefer investing in mid-term investment in a developing country such as Bangladesh, and mostly prefer high returns. The results of this report indicate that Accounting Information, Advocate Recommendation, Personal Financial Needs, Neutral Information and Self-Image are very relevant for investors in Dhaka \& Chittagong when making their investment decisions. The researcher advises that before making an investment decision, investors need to evaluate the investment factors carefully using sound business experience. Investors will need to diversify their investments in various sectors by building an investment portfolio to minimize risk and optimize returns. 


\section{REFERENCES}

1. Arkes, H. R., \& Blumer, C. (1985), the psychology of sunk costs. Organizational Behavior and Human Decision Processes, 35, 124-140.

2. Antonides, G. and N. L. Van Der Sar (1990), "Individual expectations, risk perception and preferences in relation to investment decision-making", Journal of Economic Psychology, 11(2), pp. 227-245.

3. Baker, H.K and Haslem, J.A. (1973), "Information needs of individual investors", Journal of Accountancy, Vol. 136, pp.64-9.

4. Blume, M.E and Friend, I. (1978), the Changing Role of the Individual Investor: A Twentieth Century Fund Report, Wiley, New York, NY,

5. Brockner, J. (1992). The escalation of commitment to a failing course of action: Toward theoretical progress. The Academy of Management Review, 17(1), 39-61.

6. Carter, R.B and Van Auken, H.E. (1990), "Security analysis and portfolio management: a survey and analysis", Journal of Portfolio Management, Vol. 16 No.1, pp.81-5.

7. Daniel, Kent D., David Hirshleifer and AvanidharSubrahmanyam. 1998. "Investor Psychology and Security Market Under- and Over-reactions.” Journal of Finance, 53(6): 1839-1886.

8. Epstein, M.J. (1994) "Social Disclosure and the Individual Investor", Accounting, Auditing and Accountability Journal, Vol. 4, pp. 94-109

9. Fama, E. F., 1998, "Market Efficiency, Long-Term Returns, and Behavioral Finance," Journal of Financial Economics, 49, 283-306.

10. Fisher, K. L. and M. Statman (1997), "The mean-variance optimization puzzle: security portfolios and food portfolios", Financial Analyst Journal, 53(4), pp. 41-50.

11. Francis, J. and L. Soffer (1997), 'The relative informativeness of analysts' stock recommendations and earnings forecast revisions'. Journal of Accounting Research 35, 193-211.

12. Hong, H., and J. C. Stein, 1999, A Unified Theory of Under reaction, Momentum Trading and Overreaction in Asset Markets, Journal of Finance, 54, 2143-2184.

13. Kadiyala,P. and Rau,R. (2004) "Investor reaction to corporate event announcement: Under reaction or overreaction?", Journal of Business, Vol.77.

14. Krishnan, R.and Booker, D.M. (2002) “'Investors” use of Analysts' recommendations”, Behavioral Research in Accounting, Vol.14.

15. Lee, T.A and Tweedie, D.P. (1975a), "Accounting information: an investigation of private shareholder usage", Accounting \& Business Research, autumn.

16. Lee, T.A and Tweedie, D.P. (1975b), "Accounting information: an investigation of private shareholder understanding", Accounting \& Business Research, winter.

17. Lee, T.A and Tweedie, D.P. (1976), "The private shareholder - his sources of information and his understandingof reporting practices", Accounting \& Business Research, autumn.

18. Lee, T.A and Tweedie, D.P. (1977), The Private Shareholder and the Corporate Report, Institute of Chartered Accountants in England and Wales, London, .

19. Lewellen, W.G., Lease, R.C and Schlarbaum, G.G. (1977), "Patterns of investment strategy and behavior among individual investors", Journal of Business, Vol 50 No 3 pp296-333. International Journal of Humanities and Social Science Vol. 4 No. 4 [Special Issue - February 2014] 102

20. Loughran, T., \& Ritter, J. R. (1995). The new issues puzzle. The Journal of finance, 50(1), 23-51

21. Nagy and Obenberger, (1994) "Factors influencing investor behavior", Financial Analysts Journal, Vol.50.

22. Potter, R.E. (1971), "An empirical study of motivations of common stock investors", Southern Journal of Business, Vol. 6 No.1, pp.41-4.

23. Shanthikumar,D. and Malmendier, (2003) Are small investors naive?, Stanford University Working Paper.

24. Schlarbaum, Gary G., Wilbur G. Lewellen, and Ronald C. Lease, 1978a, the common-stockportfolio performance record of individual investors: 1964-70, Journal of Finance 33, 429-441.

25. Shefrin, H. and Statman, M. 1985. "The Disposition to Sell Winners Too Early and Ride Losers Too Long: Theory and Evidence.” Journal of Finance, 40: 777-790.

26. Shefrin, H. (1999), Beyond Greed and Fear, Harvard Business School Press, Boston, MA.

27. Staw, B. M. and H. Hoang. 1995. Sunk costs in the NBA: Why draft order an ects. playing time and survival in professional basketball. Administrative Science Quarterly 40(3): 474-494

28. Weber, M. and Camerer, C. 1998. "The Disposition Effect in Securities Trading: An Experimental Analysis." Journal of Economic Behavior and Organization, 33: 167-18

29. Dr.Taqadus Bashir and AaqibaJaved (Mar. - Apr. 2013). An Assessment Study on the "'Factors Influencing the Individual Investor Decision Making Behavior" IOSR Journal of Business and Management (IOSR-JBM) e-ISSN: 2278-487X, p-ISSN: 2319-7668. Volume 9, Issue 5 (Mar. - Apr. 2013), PP 37-44 www.iosrjournals.org 